\title{
Ethnobotanical and Phytochemical Study of Bayur (Pterospermum javanicum Jungh.) on Sasak Tribe around Mount Rinjani National Park, West Lombok as a Conservation Effort
}

\author{
Putri Sri Andila ${ }^{1 *}$, Tri Warseno ${ }^{1}$, I Putu Agus Hendra Wibawa ${ }^{1}$, I Gede Tirta ${ }^{1}$ \\ 1) Bali Botanic Gardens, Research Center for Plant Conservation and Botanic Gardens, Indonesian Institute of Sciences (LIPI) Jl. \\ Kebun Raya, Candikuning, Baturiti, Tabanan 82191, Bali, Indonesia. Tel.: +62-368-2033211 \\ * Corresponding author, email: Putribot11@gmail.com
}

\begin{abstract}
Pterospermum javanicum Jungh. (Bayur) is a species belongs to the Pterospermum genera (Malvaceae). Several species of Pterospermum had been reported for their ethnobotanical usage, but the studies about ethnobotany information of Bayur and its secondary metabolite compounds were still limited which have been published. This study aimed to observe the ethnobotanical usage of Bayur and to examine the phytochemical contents of the acetone extract of Bayur flower from West Lombok. The ethnobotany information of Bayur was obtained through interviews with local people and more information on the ethnobotanical records of $P$. javanicum (Bayur) was conducted by reviewing the scientific literature. The chemical compounds of Bayur flower were analysed by the GC-MS method. The results revealed that Bayur was used by the Sasak community around Gunung Rinjani National Park West Lombok for various purposes, such as traditional medicines, beverages, rigging, and building material. The phytochemical analysis showed that the acetone extract of Bayur flower from West Lombok contained 38 identified chemical components, representing $93.78 \%$ of the total compounds. The major contents of them were Lupeyl acetate $(10.68 \%)$, p-n-Amylphenol $(8.16 \%)$, Lauric acid (7.31\%), N-(Methyl-d2)- Aniline (5,82\%), and Pentanal $(5.07 \%)$. This report was the first publication about the phytochemical contents of Bayur flower. It is expected that this study gives further information on the potentials of Bayur, especially about its secondary metabolite to support and prove the truth of the cultural concept of society in utilizing Bayur as a medicinal plant.
\end{abstract}

Keywords: Bayur Flower, Ethnobotany, GC-MS Analysis, Pterospermum javanicum

\section{INTRODUCTION}

Malvaceae is a family of the flowering plant which is comprised of around 85 genera and 1500 species, distributed widely in the tropical and temperate region (Rahman \& Gondha 2014) It has been a long time known that several species of Malvaceae have been reported as traditional medicines in many countries to treat various human diseases and disorder $(\underline{\mathrm{Al}}$ Muqarrabun \& Ahmat 2015). In India, Pterospermum acerifolium L. Willd with the local name 'Muchukunda' traditionally was used to treat for blood 
troubles, inflammation, ulcer, tumors, leprosy, for smallpox eruptions (Panda \& Dutta 2011), analgesic, for the treatment of diabetes, gastrointestinal disorders, bronchitis, cough, cephalic pain, migraine, as a haemostatic and antimicrobial agent (Datta et al. 2011). In Malaysia, Scaphium macropodum known as Kembang Semangkuk Jantung has been reported to possess medicinal properties to treat intestinal infections, diarrhea, throat aches, asthma, dysentery, fever, coughs, inflammation, and urinary illness (Al Muqarrabun et al. 2013). In Eritrean, the root Dombeya torrid with the local name Songua was used for the treatment of asthma, cough, and skin wound (Yemane et al. 2017).

Pterospermum is one of the genera belonging to the Malvaceae family, consists of approximately 30 species. It is distributed from the eastern Himalayas, South China, and Southeast Asia (Wilkie 2013). Several species of this genus have been reported for their ethnobotanical usage, especially for traditional medicine. For example, $P$. diversifolium traditionally was used to treat skin diseases (Salempa 2012) and dysentery (Hidayathulla et al. 2011). P. heyneanum Wall was used as traditional medicine for leucorrhoea disease ( $\underline{\mathrm{Al}}$ Muqarrabun \& Ahmat 2015), and P. subpeltatum was used as a cure for dysentery, toothache, and itchy drug (Salempa et al. 2009). In India, the leaves of $P$. acerifolium are widely used for diabetes treatment and as a haemostatic (Chatterjee et al. 2012). While the flowers of $P$. suberifolium are used for treating hemicrania, migraine, cephalalgia, pharyngitis, inflammations, cough, bronchitis, and skin diseases and Its leaves were used for headache treatment (Khare 2007).

Pterospermum javanicum Jungh. is a species of the genus Pterospermum known by the local name of Bayur. This species grows and spreads mainly in the lowland areas of Indonesia. Thus far, the wood of P. javanicum (Bayur) has high commercial prospects because it is classified as a wood-producing plant with durability class IV and a specific gravity of $0.35-0.70$. The wood of P. javanicum (Bayur) is commonly used as a material for making plywood, furniture, shipping, bridges, pulp, and paper (Salempa 2012). This causes the presence of $P$. javanicum (Bayur) in natural habitats increasingly threatened due to illegal logging (Hidayat 2014). Therefore, further research on the other potentials of $P$. javanicum (Bayur) will be very useful as supplementary information to increase public and government awareness in efforts to conserve the P. javanicum (Bayur) population.

Ethnobotany information showed that P. javanicum (Bayur) has several traditional functions in Indonesia and Malaya, but the scientific data has not been recorded properly. In Lombok, especially in areas inhabited by the Sasak tribe, the use of roots and stems of Bayur for traditional drinks and ethnomedicine have led to over-exploitation of Bayur in its natural habitat, so that the population of Bayur in the forest has decreased significantly. Therefore, one of the ways to overcome the overexploitation of Bayur is to encourage and increase community awareness to conserve Bayur plants.

Flowers are reproductive plant organs that are produced continuously and can be used without having to cut down the plants. Therefore, by studying the potency of Bayur flower as a substitute for roots and stems as a medicinal ingredient, it is hoped that it can reduce Bayur plants pruning for medicinal purposes to increase Bayur replantation in natural habitat. Thus far, the ethnobotany study of P. javanicum (Bayur) has been observed limitedly. There is only one scientific journal that reports on the phytochemical content of P. javanicum bark (Praptiwi \& Fathoni 2017), whereas the phytochemical contents of other parts of $P$. javanicum (Bayur) have never been conducted, including from its flower. Accordingly, the purposes of this research were to explore the ethnobotany information of P. javanicum (Bayur) and the phytochemistry potential of its flower. Therefore, the results of this study are 
expected to explore the potentials of P. javanicum (Bayur) flower, so that the plants can continue to be preserved.

\section{MATERIALS AND METHODS}

Ethnobotany Study of Pterospermum javanicum Jungh. Pterospermum javanicum Jungh (Bayur) material was collected in the natural forest of Kembang Kuning, Jeruk Manis Village, Sikur Regency, around Gunung Rinjani National Park, Lombok Island, West Nusa Tenggara Province Indonesia (S 08³1'19.18" E116²5'28.50"; altitude 794 masl) on April 2014.

The plant was identified by a taxonomist of Bali Botanic Garden, Mr. Ida Bagus Ketut Arinasa, M.Si., and the herbarium voucher was deposited in the herbarium of Tabanan Hortus Botanicus Balinese (THBB). The plant scientific name was verified using an online database (e.g. The Plant List, 2018 and The International Plant Names Index, 2018) and the description was described based on morphological observations and compare the characteristics with the available literature. We collected the potential uses of Pterospermum javanicum Jungh. through interviews with local people and information in related documents. More information on the ethnobotanical records of P. javanicum (Bayur) was conducted by reviewing the scientific literature (such as Google Scholar and Google Book) (Sujarwo 2018).

\section{Plant Material dan Sample Preparation}

Fresh materials of flowers were chopped in small size and dried without direct sun irradiance for several days until the materials were completely dry. One hundred grams of dried materials of P. javanicum (Bayur) flower was extracted with acetone by maceration method and the extract suspension was filtered by filter paper (Azwanida 2015). This extract was analyzed with a GC-MS method to identify the phytochemical components. GC-MS method to identify the phytochemical components.

\section{GC-MS Analytical Conditions and Identification of Chemical Compounds}

The acetone extract of $P$. javanicum (Bayur) flower was analyzed using the GC-MS method with the condition according to Andila et al. (2018). The GC-MS equipment was model Shimadzu GC- MS-QP2010 with an Rtx 5ms capillary column ( $60.0 \mathrm{~m} \times 25 \mathrm{~mm}$ with $0.25 \mu \mathrm{m}$ thickness) and Carrier gas UHP Helium. The conditions of GC setting was column oven at temperature of $50{ }^{\circ} \mathrm{C}\left( \pm 5\right.$ minutes to $280{ }^{\circ} \mathrm{C}$, injection temperature at 280 ${ }^{\circ} \mathrm{C}$, injection mode: split, total program time: 50 minute, flow control mode : Linear velocity, pressure : $101.0 \mathrm{KPa}$, Total Flow : $46.5 \mathrm{~mL} / \mathrm{Min}$, Column Flow: $0.85 \mathrm{~mL} / \mathrm{min}$, linear velocity: $23.7 \mathrm{~cm} / \mathrm{sec}$, purge flow $: 3.0$ $\mathrm{ml} / \mathrm{min}$, split ratio : $1: 50$,total sample injection : $1 \mu \mathrm{L}$. The MS conditions were ion source temperature: $200{ }^{\circ} \mathrm{C}$, interface temperature: $280{ }^{\circ} \mathrm{C}$, solvent cut time: $1.5 \mathrm{~min}$, and detector temperature $280^{\circ} \mathrm{C}$. Mass spectra fragmentation patterns were used to identify the chemical compounds.

Data Analysis

Information on the ethnobotany studies of P. javanicum (Bayur) was obtained through interviewing with local informants and reviewing scientific literature database. The data obtained were tabulated and discussed descriptively. While to determine the names of chemical compounds of GC-MS results were approved by comparing each retention time indices, and mass spectra fragmentation patterns data with those from computer library WILEY7.LIB and open published literature (Andila et al. 2018). 


\section{RESULTS AND DISCUSSION}

Description of Pterospermum javanicum Jungh. (Bayur)

The name of Pterospermum javanicum Jungh. (Bayur) was described as a medium-size to a large tree, Emergent up to $59 \mathrm{~m}$ tall and $54 \mathrm{~cm}$ diameter at breast height $(\mathrm{DBH})$. Stipules $5 \mathrm{~mm}$ long. Leaves alternate, simple, tripleveined, undersurface whitish-brownish, hairy, leaf base asymmetrical. Flowers $100 \mathrm{~mm}$ diameter, yellowish, with very long and narrow petals, flowers placed in racemes. Fruits $104 \mathrm{~mm}$ long, green-brown, hairy, dehiscent capsules filled with many winged seeds (Whitmore 1972; Wilkie 2013). This species occurs scattered in undisturbed to disturbed (open sites) mixed dipterocarp forests, up to $1,400 \mathrm{~m}$ of altitude. Usually on ridges or river banks. It was also found on limestone. Distributed from India, Myanmar, Thailand, Malaya, Sumatra, Java, Borneo, and New Guinea (Whitmore 1972).

Ethnobotany Study of Pterospermum javanicum Jungh. (Bayur) Based on interviews, the potential use of Bayur (P. javanicum) on Sasak Tribe around Gunung Rinjani National Park, West Lombok was described in Table 1. Their usage specifically as traditional medicine and traditional beverage (Salempa et al. 2014). Based on the collected data of Bayur application, informants also utilize the wood for furniture, house, boat, and bridge material. They are also use the wood for weathercock (weather control tools), berugak, and lumbung. Weathercock is usually placed in the garden near the house and it makes a nice and unique sound. A berugak, or gazebo, stands out front, while a lumbung, or rice barn, sits in the back. A berugak usually is square or rectangular with a thatch (alang-alang) roof, timber floor, and either four poles (sekepat) or six poles (sekenem), often of jackfruit or coconut wood. The berugak is an open-air structure which is separated from the house and it is part of the philosophy of life of the island's indigenous Sasak people.

Comparative analysis with previous research on the ethnobotany study of Bayur both in the Lombok region and in other areas was also described in this paper. Johnson (1998) in his book "Ethnobotany Desk Reference" revealed that In Java and Malaya, P. javanicum (Bayur) has been used as a dentifrice and to treat several human diseases such as dysentery, gingivitis, inflammation, sore, sprains, and abdomen disorder. In Lombok, especially for the local community around the Mount Rinjani area, the root of $P$. javanicum (Bayur) was used as raw material for traditional beverage, with a local name of "Tuak Bayur". The local people believe that this traditional beverage can be used for diabetes treatment (Hidayat 2014). Bayur root added to palm sap (Arenga pinnata) serves as a tuak preservative. Another study also found that the Sesaot tribe community in West Lombok (West Nusa Tenggara) uses the mixture of roots of P. javanicum (Bayur) and water to treat haemorrhoids (Hidayat \& Pendit 2012). While Sukenti et al. (2016)

Table 1. Potencial Use of P. javanicum Jungh. on Sasak Tribe in around Gunung Rinjani National Park, West Lombok..

\begin{tabular}{clcccc}
\hline & & \multicolumn{5}{c}{ Potencial Use } \\
\cline { 3 - 6 } NO & Part of Plant & $\begin{array}{c}\text { Traditional } \\
\text { Medicine }\end{array}$ & $\begin{array}{c}\text { Food and } \\
\text { Beverage }\end{array}$ & $\begin{array}{c}\text { Rigging } \\
\text { material }\end{array}$ & $\begin{array}{c}\text { House } \\
\text { construction/ } \\
\text { furniture }\end{array}$ \\
\hline 1 & Bark & + & + & + & - \\
2 & Leaf & - & - & - & - \\
3 & Root & + & - & - & - \\
4 & Stem & + & - & - & + \\
5 & Wood & - & - & - & + \\
\hline
\end{tabular}


found that the local cuisine of the Sasak tribe in Lombok Island used stem bark of P. javanicum (Bayur) as a traditional beverage. In West Nusa Tenggara, Bayur was also used as a building material and food flavoring (Dharma et al. 2017). Specifically, the medicinal use of P. javanicum base on the literature study was performed in Table 2 .

Table 2. Medicinal Use of P. javanicum Jungh.

\begin{tabular}{|c|c|c|c|c|}
\hline No. & $\begin{array}{l}\text { Part of } \\
\text { Plant }\end{array}$ & Medicinal use & $\begin{array}{l}\text { Processes/ } \\
\text { preparation }\end{array}$ & References \\
\hline \multirow[t]{3}{*}{1.} & Root & Diabetes drug & $\begin{array}{l}\text { Roots are sliced } \\
\text { into small pieces, } \\
\text { then mixed in } \\
\text { Bayur Tuak and } \\
\text { drunk }\end{array}$ & (Hidayat 2017) \\
\hline & & Haemorrhoid & $\begin{array}{l}\text { (base on scientific } \\
\text { research) }\end{array}$ & $\begin{array}{l}\text { (Hidayat \& Pendit } \\
\text { 2012) }\end{array}$ \\
\hline & & Tonic & $\begin{array}{l}\text { Mixed in bayur } \\
\text { tuak (tradisional } \\
\text { drink) }\end{array}$ & $\begin{array}{l}\text { Interview; } \\
\text { (Dharma et al. } \\
\text { 2017); ( } \text { Hidayat \& } \\
\text { Pendit 2012) }\end{array}$ \\
\hline \multirow[t]{3}{*}{2.} & Bark & $\begin{array}{l}\text { Dysentery, } \\
\text { Toothache, } \\
\text { Ulcers and } \\
\text { sprains }\end{array}$ & $\begin{array}{l}\text { (as an ingredient } \\
\text { of thnomedicine) }\end{array}$ & ( \\
\hline & & Antibacterial & $\begin{array}{l}\text { (base on scientific } \\
\text { research) }\end{array}$ & $\begin{array}{l}\text { (Praptiwi \& } \\
\text { Fathoni 2017) }\end{array}$ \\
\hline & & Antioxidant & $\begin{array}{l}\text { (base on } \\
\text { scientific } \\
\text { research) }\end{array}$ & $\begin{array}{l}\text { (Saefudin et al. } \\
\underline{2013} \text { ) }\end{array}$ \\
\hline
\end{tabular}

The Chemical Constituents of Acetone Extract of The Flower of $\boldsymbol{P}$. javanicum (Bayur) from Lombok

This study was carried out to determine the possible chemical compounds of acetone extract of $P$. javanicum (Bayur) flower from Lombok by GC-MS method. The complete result of the GC-MS analysis was shown in Table 3 and its chromatogram in Figure 1. This study revealed that the acetone extract of $P$. javanicum (Bayur) flower contained 38 identified chemical components, consisting of $93,78 \%$ of the total determined contents. The dominant compounds were Lupeyl acetate (10.68\%), p-n-Amylphenol (8.16\%), Lauric acid (7.31\%), N-(Methyl-d2)-Aniline (5,82\%), and Pentanal $(5.07 \%)$. As far as the author's investigation, this report was the first publication about the phytochemical contents of P. javanicum flower.

Moreover, Higher plants produce both primary and secondary metabolites. Adopting a phytochemical analysis approach for preliminary screening of plant's secondary metabolites seemed to be reasonable to obtain comparative information about the main group of secondary metabolites among those plants (Edriss et al. 2012). Plant secondary metabolites exhibit a wide composition of biological and pharmacological properties. Because of this, some medicinal products were derived from them and used to treat various infections and diseases (Wink 2015).

In this research, the study about screening phytochemical properties of P. javanicum (Bayur) flower was conducted by the GC-MS method. This method was chosen according to a previous study about phytochemical properties of bark extract of P. javanicum by Praptiwi and Fathoni (2017). The results showed that the flower of $P$. javanicum (Bayur) contained 38 identified chemical components with main properties consisted of Lupeyl acetate (10.68\%), p-n-Amylphenol (8.16\%), Lauric acid (7.31\%), N-(Methyl-d2)- 
Aniline (5,82\%), and Pentanal (5.07\%). These components were quite different from the chemical compounds contained in Bark of $P$. javanicum. Praptiwi and Fathoni (2017) reported that the phytochemical compounds in the bark of $P$. javanicum (Bayur) consisted of 31 identified chemical compounds with dominant properties: stigmast-4-en-3-one $(19.68 \%), \gamma$ sitosterol (19.81\%), and 4,22-Cholestadien-3-one 9 (9.09\%). Thus far, there are only two of these publications which have reported on the phytochemical contents of P. javanicum.

Some of the compounds identified in Bayur flower extract have pharmacological potential. Lupeyl acetate has potential as an anticancer, Leishmanicidal, and anti-inflammatory. (Suwito et al. 2016) reported that Lupeyl acetate, a major constituent of the bark of Artocarpus integra has anticancer activity. Juárez-vázquez et al. (2020) also found that Lupeol Acetate isolated from Cnidoscolus tehuacanensis showed potential as a Leishmanicidal and anti-inflammatory. Several compounds such as p-nAmylphenol (Shapiro \& Guggenheim 1998), lauric acid (Anzaku et al. 2017), acetic acid (Iroha et al. 2011), ethyl methacrylate (Rawlinson et al. 2010) and p-Vinylguaiacol are known to have antibacterial activity. p-Vinylguaiacol (Ravikumar et al. 2012), and 2,6-Dimethoxyphenol (Yang et al. 2016) showed high antioxidant activity, while Lauric acid and Linoleic acid (Choi 2014) have potential as medicine for cancer treatment (Lappano et al. 2017). Several compounds have also been identified to have anti-inflammatory activity, among others: p-Ethylguaiacol (Zhao et al. 2019), p-Vinylguaiacol (Ravikumar et al. 2012), 4-Allyl-2,6-dimethoxypheno (Xie et al. 2015), Eicosane and pentadecane (Okechukwu 2020). Eicosane and pentadecane were able to show very strong analgesic, and antipyretic effects (Okechukwu 2020). Indole was used for several diseases, such as muscle relaxants, antileukemic, neurotransmitter in the CNS, and also in the cardiovascular and gastrointestinal systems (Kaushik et al. 2013). These data support the fact that $P$. javanicum has been used by the Sasak people around Gunung Rinjani National Park as a traditional medicine to treat diseases.

As comparative studies, several secondary metabolite profiling of other species in Pterospermum genera have been recorded in scientific journals. Al Muqarrabun and Ahmat, (2015) found that P. heyneanum (stem) contained terpenoids (Cyclopterospermol, 30 norcyclopterospermol, 30norcyclopterospermone), and Miscellaneous compounds (n-octacosanol, 3hydroxy-5-methoxy-2-methylbenzoquinone. While Salempa (2012) reported that the chloroform fraction of $P$. subpeltatum extract contained steroid, a non -aromatic compound. Other studies revealed that flowers of $P$. acerifolium contained various chemical compounds, among other Phenyl propanoid ( $\mathrm{p}$ coumaric acid), flavonoids (Apigenin, 3'-methoxy-apigenin, Apigenin-7-b-Oneohesperidoside, 56 Luteolin, Luteolin 7-O-glucoside, Luteolin-7-b-Oneohesperidoside, Vitexin, Pterospermin B, Pterospermin A, Transtiliroside), Terpenoids ((6R,9S)-3-oxo-a-ionol-b-D-glucopyranoside, Linalool3-rutinoside, Friedelan-3a-ol, Friedelan-3b-ol, b-amyrin), and miscellaneous compounds (1-undecene, pterospermin C, and (3R,4R,5S)-3,4-dihydroxy-5methyl-dihydrofuran-2-one) (Dixit et al. 2011). While the bark of $P$. acerifolium was rich in bioactive constituents like phenol $(2.36 \%)$, alkaloid $(2.10 \%)$, flavonoid (1.84\%), and tannin $(2.16 \%)$. P. acerifolium also contained high total antioxidant content in its bark (Rath et al. 2014) and leaves (Chatterjee et al. 2012; Sannigrahi et al. 2010).

Based on the results of this study, it can be seen that the chemical content contained in Bayur flowers can be associated with different pharmacological activities including antibacterial, antioxidant, antiinflammatory, and analgesic properties, which can justify and confirm the indication of traditional therapeutic preparations based on plants. So it is 
hoped that bayur flowers can be used as an alternative material for traditional medicinal materials other than roots and bark which in practice tends to damage and kill the plants.

Table 3. The result of GCMS analyses obtained from acetone extract of Pterospermum javanicum Jungh. flower.

\begin{tabular}{|c|c|c|c|c|}
\hline Peak & Chemical Name & R.Time & $\begin{array}{l}\text { Conc. } \\
\text { Relative } \\
(\%)\end{array}$ & SI \\
\hline 1 & 2-Propynoic Acid & 1.733 & 1.07 & 98 \\
\hline 2 & Acetic acid & 2.170 & 3.81 & 97 \\
\hline 3 & Cyclohexanone & 8.641 & 2.87 & 87 \\
\hline 4 & IZAL & 9.816 & 4.09 & 96 \\
\hline 5 & Corylon & 10.303 & 1.58 & 95 \\
\hline 6 & N-(Methyl-d2)-Aniline & 11.078 & 5.82 & 82 \\
\hline 7 & Pentanal & 11.243 & 5.07 & 87 \\
\hline 8 & $\begin{array}{l}\text { 3-Ethyl-2-hydroxy-2-cyclopenten-1 } \\
\text {-one }\end{array}$ & 11.488 & 0.93 & 92 \\
\hline 9 & m-Ethylphenol & 12.126 & 1.34 & 79 \\
\hline 10 & Creosol & 12.295 & 1.51 & 94 \\
\hline 11 & Ethyl methacrylate & 12.588 & 1.15 & 81 \\
\hline 12 & $\begin{array}{l}\text { 1-hydroxy-4,4-dimethyl- } \\
\text { cyclohexanecarbonitrile }\end{array}$ & 12.745 & 0.76 & 68 \\
\hline 13 & p-Ethylguaiacol & 13.173 & 0.88 & 86 \\
\hline 14 & Indole & 13.485 & 2.28 & 95 \\
\hline 15 & p-Vinylguaiacol & 13.549 & 2.86 & 87 \\
\hline 16 & 4,4-Dimethylbut-2-enolide & 13.694 & 0.69 & 77 \\
\hline 17 & 2,6-Dimethoxyphenol & 13.891 & 3.53 & 90 \\
\hline 18 & $\mathrm{n}$-Tetradecane & 14.086 & 2.02 & 79 \\
\hline 19 & 3-Methylindole & 14.341 & 0.93 & 92 \\
\hline 20 & 1,2,4-Trimethoxybenzene & 14.725 & 0.65 & 82 \\
\hline 21 & Phenol, 2-methoxy-3-(2-propenyl)- & 14.775 & 1.09 & 93 \\
\hline 22 & $\begin{array}{l}\text { benzenemethanol, .alpha.-(2- } \\
\text { aminocyclopentyl)- }\end{array}$ & 15.158 & 0.55 & 69 \\
\hline 23 & Lauric acid & 15.590 & 7.31 & 97 \\
\hline 24 & 1,2-Epoxy-3-propyl acetate & 15.658 & 1.06 & 78 \\
\hline 25 & $\begin{array}{l}\text { 4-methyl-2,5- } \\
\text { dimethoxybenzaldehyde }\end{array}$ & 15.725 & 1.29 & 70 \\
\hline 26 & 4-Allyl-2,6-dimethoxyphenol & 16.762 & 0.55 & 92 \\
\hline 27 & n-phenyl-n'-furaldehyde hydrazone & 17.052 & 0.73 & 71 \\
\hline 28 & Coniferyl alcohol & 17.158 & 3.74 & 85 \\
\hline 29 & 1-Hexadecyne & 18.007 & 0.82 & 84 \\
\hline 30 & Palmitic acid & 18.404 & 4.51 & 96 \\
\hline 31 & decane, 2,3,5,8-tetramethyl- & 18.542 & 1.72 & 87 \\
\hline 32 & Nonadecane & 19.163 & 0.49 & 92 \\
\hline 33 & Linoleic acid & 19.520 & 4.44 & 94 \\
\hline 34 & Stearic acid & 19.633 & 1.66 & 95 \\
\hline 35 & Octacosane & 19.758 & 0.71 & 90 \\
\hline 36 & Myristamide & 19.823 & 0.43 & 85 \\
\hline 37 & p-n-Amylphenol & 24.005 & 8.16 & 86 \\
\hline \multirow[t]{4}{*}{38} & Lupeyl acetate & 42.128 & 10.68 & 87 \\
\hline & Total & & 93.78 & \\
\hline & Phenol & & 12.7 & \\
\hline & Terpenoid (Triterpene) & & 10.68 & \\
\hline
\end{tabular}

Note: R.Time: Retention Time; Conc. Relative: Concentration Relative; SI:

Similarity Index. 


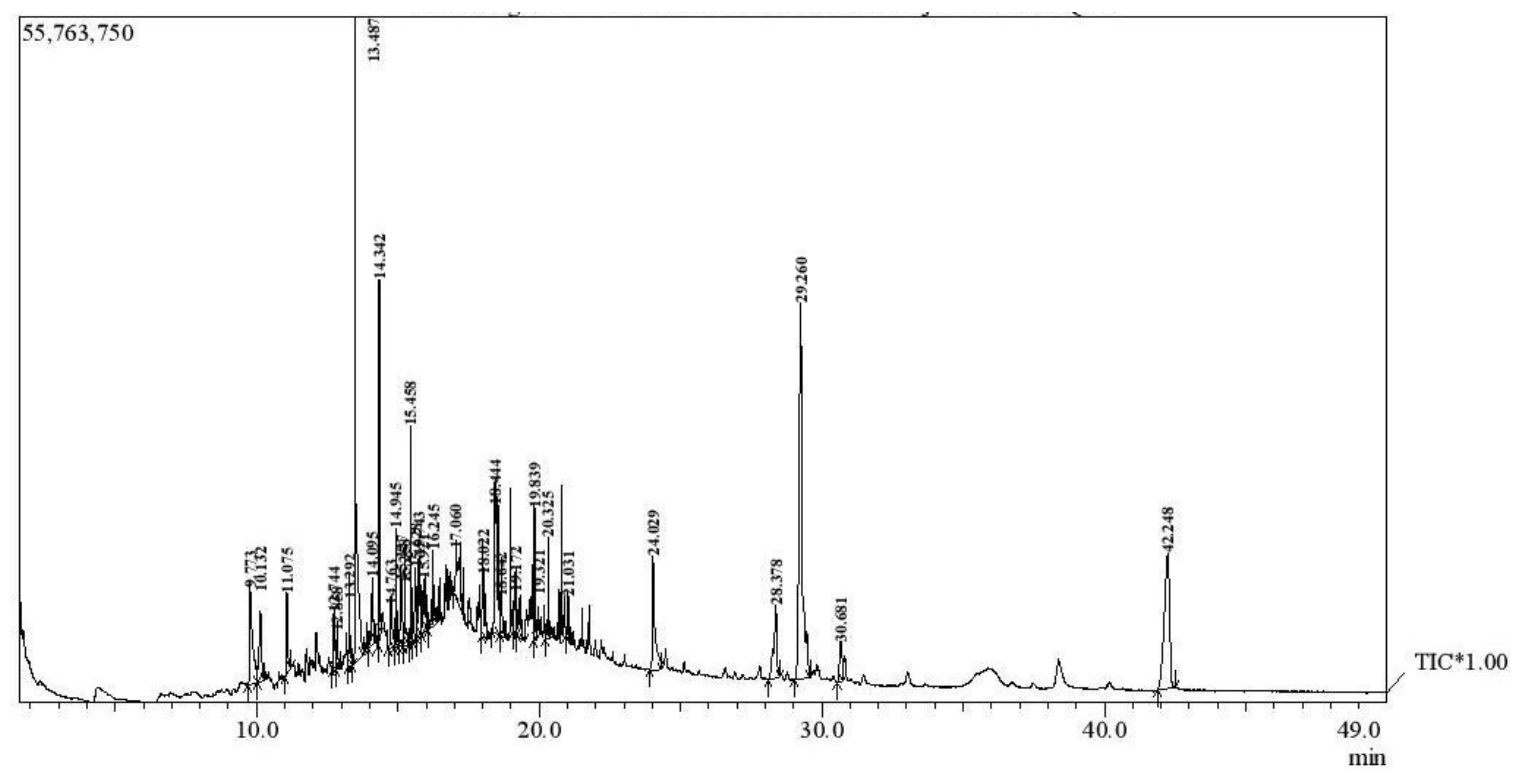

Figure 1. GCMS chromatogram of the acetone extract of Pterospermum javanicum Jungh flower.

\section{Pterospermum javanicum Jungh. Conservation Issues}

Since there are no major threats envisaged for this taxon, there are no recommendations on conservation action at this point. This species was evaluated as Least Concern (Ganesan 2020). But the utilization of $P$. javanicum Jungh. from the forest by the Sasak people also needs to be evaluated in terms of the long term conservation prospects for this species.

Nowadays, conservation requires a multidisciplinary approach, including the integration of local indigenous knowledge. It is a very important thing for conservation and sustainable management of natural resources, especially for the medicinal used of forest products instead of pure timber harvesting (Nahdi et al. 2016; Pieroni et al. 2014; Shrestha \& Kimberly 2017). So that the utilization of P. javanicum as traditional medicine and beverage by the local community in Lombok can be a sustainable basis in order to conserve the $P$. javanicum population in those areas. In addition, by knowing the chemical content of Bayur flowers, it is hoped that the community can use it as an alternative material for making traditional medicines because the use of flowers is much safer for plant survival when compared to the use of their stem bark or roots.

\section{CONCLUSION}

The investigation about ethnobotany studies showed that $P$. javanicum (Bayur) have been used by the local community in Lombok for various ethnobotanical purposes: traditional medicine and beverages, rigging, and house (building) material.

The phytochemical analysis revealed that the acetone extract of $P$. javanicum (Bayur) flower from Sumbawa contained 38 identified chemical components, representing $93,78 \%$ of the total compounds. The major contents of them were Lupeyl acetate (10.68\%), p-n- Amylphenol (8.16\%), Lauric acid (7.31\%), N-(Methyl-d2)-Aniline (5,82\%), and Pentanal (5.07\%). This report was the first publication about the phytochemical contents of $P$. javanicum (Bayur) flower. This present study also indicated that $P$. javanicum (Bayur) flower contained phenolic compounds and triterpenoid, lupeyl acetate which had great potential for human medicine. By knowing the chemical content of Bayur flowers, it is hoped that the community can use it as an alternative material for making traditional medicines and support the conservation of Bayur. 


\section{AUTHORS CONTRIBUTION}

P. S. A. designed the research, wrote the manuscript and supervised all the process. T. W. designed the research, wrote the manuscript, and reviewed the manuscript, I G. T. designed and collected the ethnobotani data. I P. A. H. $\mathrm{W}$. designed and collected the ethnobotani data.

\section{ACKNOWLEDGMENTS}

The authors would like to thank the Ministry of Research and Technology / National Research and Innovation Agency of the Republic of Indonesia, as a SAINTEK scholarship provider for funding this publication. We declare that Putri Sri Andila and Tri Warseno are the main contributor and I Putu Agus Hendra Wibawa and I Gede Tirta are the member contributor.

\section{CONFLICT OF INTEREST}

The authors declare that there is no any conflict of interest regarding the research or the research funding.

\section{REFERENCES}

Al Muqarrabun, L. M. R. et al., 2013. Chemical Constituents of Two Malaysian Medicinal Plants : Scaphium macropodum (Sterculiaceae) and Sapium baccatum (Euphorbiaceae ). In 300 The Open Conference Proccedings Journal, 2013, Volume 4 Proceedings of the ICNP 2013 P-212, pp.212-300.

Al Muqarrabun, L. M. R., \& Ahmat, N., 2015. Medicinal uses, phytochemistry and pharmacology of family Sterculiaceae : A review, European Journal of Medicinal Chemistry, 92, pp.514-530.

Andila, P. S. et al., 2018. First report from Indonesia, phytochemical composition of essential oils from leaves and fruits of Zanthoxylum avicennae (Lam.) DC., Journal of Biological Researches, 23(2), pp.101-106.

Anzaku, A. A. et al., 2017. Antibacterial Activity of Lauric Acid on Some Selected Clinical Isolates, IMedPub Journals, 5(2), pp.1-5.

Azwanida, N., 2015. A Review on the Extraction Methods Use in Medicinal Plants, Principle, Strength and Limitation, Medicinal \& Aromatic Plant, 4 (3), pp. 3-8.

Chatterjee, P. et al., 2012. Pterospermum acerifolium Linn. : A comprehensive review with significant pharmacological activities, International Journal of Pharmacy \& Life Sciences, 3(2), pp.1453-1458.

Choi, Y. H., 2014. Linoleic Acid-Induced Growth Inhibition of Human Gastric Epithelial Adenocarcinoma AGS Cells is Associated with Down-Regulation of Prostaglandin E 2 Synthesis and Telomerase Activity, Journal of Cancer Prevention, 19(1), pp.31-38.

Datta, R. et al., 2011. Anti-inflammatory, Analgesic and Anti-pyretic Activity of the Leaves of Pterospermum acerifolium, Journal of Pharma Sci Tech, 1(1), pp. 35-40.

Dharma, I. D. P. et al., 2017, Koleksi Kebun Raya Lombok Tumbuban Sunda Kecil. (J. R. Witono \& S. Hidayat, Eds.) (1st ed.), Jakarta: LIPI Press.

Dixit, P. et al., 2011. Bioorganic \& Medicinal Chemistry Letters Osteogenic constituents from Pterospermum acerifolium Willd. flowers, Bioorganic \& Medicinal Chemistry Letters, 21(15), pp.4617-4621.

Edriss, A. E. et al., 2012. Phytochemical screening of important secondary metabolites in some extracts of two Sudanese plants, Global Advanced Research Journals, 1(8), pp.199-202.

Ganesan, S. . K., 2020. Pterospermum javanicum. The IUCN Red List of Threatened Species 2020: e.T61787032A61787059. http://doi.org/ https://dx.doi.org/10.2305/IUCN. UK.2020-

$$
\text { 1.RLTS.T61787032A61787059.en }
$$


Heyne, K., 1987, Tumbuban Berguna Indonesia III. Jakarta: Badan Litbang Kehutanan.

Hidayat, S., \& Pendit, M. R., 2012. Bayur (Jungh.) bahan minuman kesehatan bagi Masyarakat Sesaot, Lombok Barat, Nusa Tenggara Barat, In Seminar Nasional Aspek Budaya, Kebijakan dan Filosofi Sains Jamu (pp. 9799). Bogor: Biopharmaca Research Centre, IPB.

Hidayat, S., 2014. Pola Sebaran dan Asosiasi Bayur (Pterospermum javanicum Jungh.) di Kawasan Taman Nasional Gunung Rinjani, Jurnal Penelitian Hutan Dan Konservasi Alam, 11(3), pp.225-237.

Hidayat, S., 2017. The use by local communities of plants from Sesaot Protected Forest, West Nusa Tenggara, Indonesia, Biodiversitas, 18(1), pp.238-247.

Hidayathulla, S., K, K. C., \& Chandrashekar, K. R., 2011. Phytochemical Evaluation and Antibacterial Activity of Pterospermum diverifolium Blume, International Journal of Pharmacy and Pharmaceutical Sciences, 3(2), pp.6-8.

Iroha, I. R. et al., 2011. Antimicrobial Activity os Savlon, Izal, and Zgermicide Against Clinical isolates of Pseudomonas aeruginosa from Hospital Wards. European Journal of Dentistry and Medicine, 3(1), pp.3235.

Johnson, T., 1998, Ethnobotany Desk Reference . Washington DC Amerika: CRC Press.

Juárez-vázquez, M. C. et al., 2020. Leishmanicidal and anti-inflammatory activities of Lupeol Acetate isolated from Cnidoscolus tehuacanensis Breckon Medicinal \& Aromatic Plants. Med Aromat Plants, 9(3(347)): pp.1-11.

Kaushik, N. K. et al., 2013. Biomedical Importance of Indoles, Molecules, 18, pp.6620-6662.

Khare, C. P., 2007, Indian Medicinal Plants. In Indian Medicinal Plants. Berlin/ Heidelberg: Springer.

Lappano, R. et al., 2017. The lauric acid-activated signaling prompts apoptosis in cancer cells. Cell Death Discovery, 3(17063), pp.1-9.

Nahdi, M. S. et al., 2016. The ethnobotany of medicinal plants in supporting the family health in Turgo, Yogyakarta, Indonesia. Biodiversitas, 17(2), pp.900-906.

Okechukwu, P. N., 2020. Evaluation of anti-inflammatory, analgesic, antipyretic effect of eicosane, pentadecane, octacosane, and heneicosane, Asian Journal of Pharmaceutical and Clinical Research, 13(4), pp.29-35.

Panda, S. K., \& Dutta, S. K., 2011. Antibacterial activity from bark extracts of Pterospermum acerifolium (L.) Willd. International Journal of Pharmacentical Sciences and Research, 2(3), pp.584-595.

Pieroni, A. et al., 2014. Local Knowledge on Plants and Domestic Remedies in the Mountain Villages of Peshkopia (Eastern albania), J.Mt.Sci, 11(1), pp.180-193.

Praptiwi, \& Fathoni, A., 2017. GC / MS profiling and evaluation of antibacterial and antioxidant activities of bayur (Pterospermum javanicum) bark, Teknologi Indonesia, 40(1), pp.12-19.

Rahman, A. H. M. M., \& Gondha, R., 2014. Taxonomy and Traditional Medicine Practices on Malvaceae (Mallow Family of Rajshahi, Bangladesh, Open Journal of Botany, 1(2), pp.19-20.

Rath, S. K. et al., 2014. Chemical profiling and evaluation of bioactivity of solvent extracts of Pterospermum acerifolium Linn.: an ethnomedicinal chemical profiling and evaluation of bioactivity of solvent extracts of Pterospermum acerifolium Linn.: World Journal of Pharmacy and Pharmacentical Sciences, 3(3), pp.1862-1874. 
Ravikumar, V. R. et al., 2012. Analysis of Phytochemical Constituents of Stem Bark Extracts of Zanthoxylum, Research Journal of Pharmaceutical, Biological and Chemical Sciences, 3(4), pp.391-402.

Rawlinson, L. B. et al., 2010. Antibacterial Effects of Poly (2(dimethylamino ethyl) methacrylate) against Selected Gram-Positive and Gram-Negative Bacteria, Biomacromolecules, 11, pp.443-453.

Saefudin et al., 2013. Tumbuhan sterculiaceae (Antioxidan Activity on Six Species of Sterculiacea Plants), Jurnal Penelitian Hasil Hutan, 31(2), pp.103-109.

Salempa, P. et al., 2009. Uji Toksisitas Ekstrak methanol Beberapa Bagian Jaringan Tumbuhan Bayur (Pterospermum subpeltatum C.B. Rob.), Indonesia Chimica Acta, 2(2), pp.18-26.

Salempa, P., 2012. Phyitosteroid from Chloroform Fraction of Wood Roots Bayur (Pterospermum subpeltatum C.B. Rob) Extract, Jurnal Chemica, 13(2), pp.47-50.

Salempa, P. et al., 2014. The Antibacterial Properties of Bayur Tissues' Extract Pterospermum subpeltatum C.B. Rob), Jurnal Teknologi, 69(5), pp.87 $-89$.

Sannigrahi, S. et al., 2010, Antioxidant and anti-inflammatory potential of pterospermum acerifolium, International Journal of Pharmaceutical Sciences Review and Research, 2(1), pp.1-5.

Shapiro, S., \& Guggenheim, B., 1998. QSAR Inhibition of Oral Bacteria by Phenolic Compounds, Quant. Struct.Act. Relat., 17, pp.327-337.

Shrestha, A., \& Kimberly, E., 2017. Integrating ecological and ethnobotanical knowledge to promote collaborative conservation planning in the Nepal Himalaya, Mountain Research and Development, 37(1), pp.97-107.

Sujarwo, W., 2018. Bamboo resources, cultural values, and ex-situ conservation in Bali, Indonesia, Reinwardtia, 17(1), pp.67-75.

Sukenti, K. et al., 2016. Ethnobotanical study on local cuisine of the Sasak tribe in Lombok Island, Indonesia, Journal of Ethnic Foods, 3, pp.189_ 200.

Suwito, H. et al., 2016. Isolation, transformation, anticancer, and apoptosis activity of lupeyl acetate from Artocarpus integra. In 5 th International Conference and Workshop on Basic and Applied Sciences (ICOWOBAS 2015), 80004, pp.1-8. the American Institute of Physics.

Whitmore, T., 1972, Tree flora of Malaya: A manual for foresters, Kuala Lumpur, Longman Malaysia Sdn. Berhad.

Wilkie, P., 2013. A new species of Pterospermum Schreb. (Dombeyoideae, Malvaceae/Sterculiaceae) from southern Thailand, Thai for Bull. (Bot.), 41, pp.10-12.

Wink, M., 2015. Review: Modes of Action of Herbal Medicines and Plant Secondary Metabolites, Medicines, 2, pp.251-286.

Xie, Y. et al., 2015. Anti-inflammatory phenolic glycosides from Liparis odorata, Medical Chemistry Research, 24, pp.356-361.

Yang, J.-F. et al., 2016. Antibacterial Activity of Wood Vinegar from Litchi chinensis. Molecules, 21(1150), pp.1-10.

Yemane, B. et al., 2017. Survey of Some Common Medicinal Plants Used in Eritrean Folk Medicine, IMedPub Journals, 4(2), pp.1-8.

Zhao, D. et al., 2019. Anti-inflammatory Mechanism Involved in 4 Ethylguaiacol- Mediated Inhibition of LPS-Induced In fl ammation in THP - 1 Cells, Journal of Agricultural and Food Chemstry, 67, pp.12301243. 